\title{
TWO NEW SPECIES OF PROSTANTHERA FROM NEW SOUTH WALES.
}

\author{
By R. T. Baker, F.L.S., Assistant Curator Technological \\ Museum, Sydney.
}

(Plates xxII.-XxiII.)

\section{Prostanthera discolor, sp.nov.}

\section{(Plate xxii.)}

A tall slender shrub, 6 to 9 feet high, branches terete, branchlets only slightly angular; branches, branchlets, and calyx very hoary; branchlets slender and often nodding.

Leaves quite glabrous, lanceolate or oblong-lanceolate, obtuse, narrowing into a petiole 2 to 3 lines long, $\frac{3}{4}$ to over an inch long and $1 \frac{1}{2}$ to rarely 3 or 4 lines broad, flat, entire, light underneath, dark coloured above, the midrib very prominent on the underside, particularly towards the petiole, but impressed above.

Flowers small in terminal compact heads or racemes, floral leaves reduced in size and very deciduous. Pedicels short, about half the length of the calyx. Calyx striate, very hoary pubescent particularly towards the base, the lips "blue," $1 \frac{1}{2}$ lines long, both lips entire, the upper one slightly longer than the lower, and not so broad. Corolla about twice as long as the calyx, minutely pubescent, the lower lip exceeding the others. Stamens not exserted. Anthers mostly without any appendage to the connective, in fact, only rarely present, quite glabrous.

Hab. - At the foot of Cox's Gap Road, Murrumbo, Goulburn River, N.S.W. (R.T.B.)

As the anther appendages are only rarely met with in this species it might perhaps be placed in the Section Klanderia of Bentham's Table of the species of this genus, but the corolla is not similar in shape to that described under this group, and as this latter feature is such a well marked characteristic I have 
preferred to refer the species under consideration to the Section Euprostanthera. I am influenced in such a decision by its mode of inflorescence as well as by the fact that one or two species with only rudimentary appendages are already included in this Section.

In the species of Section Klanderia of Prostanthera the corolla tube is so very distinctive, being "narrow at the base, usually incurved and dilated upwards, the upper lip erect, concave or arched, the lower lip shorter or at any rate not longer and spreading," whilst in this species the corolla tube has the lower lip longer than the lobes, is not incurved or narrow at the base,points that would not justify its being classified with this Section.

Neither can it be included under any of the species enumerated under Bentham's Series Convexæ and Subconcavæ, as all those have axillary flowers and anthers with one appendage about twice as long as the cell.

Of the species described under Euprostanthera it most resembles $P$. rotundifolia and $P$. violacea in its close terminal racemes, but differs from them in the form and size of its leaves, shape of corolla, and, of course, virtual want of anther appendages.

It also differs from $P$. incana, $P$. hirtula, and $P$. denticulata in its leaves being perfećtly flat, also in inflorescence, indumentum, and absence of anther appendages; and for the same reason it is excluded from $P$. rugosa, $P$. marifolia, $P$. rhombea, $P$. spinosa, P. cuneata, $P$. linearis, $P$. phylicifolia, $P$. decussata, and $P$. empetrifolia.

Its greatest affinity is perhaps with $P$. incisa and $P$. Sieberi, but its leaves are so distinctly or uniformly entire that I prefer to regard it as a connecting link between those two species and $P$. rotundifolia. From the description of $P$. incisa one might be led to think it was that species, but when specimens of each are placed side by side the differences are very marked.

From the above considerations I conclude that in botanical sequence it should come after either $P$. incisa or P. Sieberi, and be followed by $P$. rotundifolia. 


\section{Prostanthera stricta, sp.nov.}

(Plate xxiII.)

A densely bushy shrub, drying black, with hirsute, terete branches and branchlets.

Leaves petiolate, lanceolate, sometimes broadly so, decussate, obtuse, entire, the margins recurved, scabrous-hispid above, bullaterugose, dark coloured on the upper surface, whitish underneath, 4.9 lines long, 2-3 or even 4 lines broad, the midrib and lateral veins prominent underneath and impressed above, giving the surface a bullate appearance.

Flowers opposite, in pairs in terminal compact cylindrical spikes or racemes, occasionally leafy at the base. Pedicels slender, above 1 line long. Bracts linear-subulate, almost as long as the calyx. Calyx $1 \frac{1}{2}$ to 2 lines long, strongly ribbed towards the base, hirsute, glabrous inside except towards the mouth, where it is hoary pubescent, lips of about equal length and orbicular when surrounding the fruit. Corolla not twice the length of the calyx, glabrous, the lower lip longer than the other lobes. Anthers with one appendage exceeding the cell, the other adnate and shorter.

Hab.-Mt. Vincent, near Ilford, Mudgee Road, N.S.W.

The compact terminal spikes or racemes give the plant a distinctive appearance, and by this mode of inflorescence it naturally falls into Bentham's Series R a c e m o s æ.

Its nearest ally in that Series is perhaps $P$. denticulata, that species resembling it somewhat in its leaves but not in inflorescence, indumentum, disposition of leaves, or anther appendages.

Its leaves bear a strong likeness also to those of $P$. rugosa and $P$. marifolia, but the attachment is quite different, and it differs also from these two species in its terminal inflorescence. It is also a much more rigid shrub than $P$. marifolia. The arrangement of its leaves would incline one from a casual examination to designate it $P$. decussata, - a Victorian species found on the rocky summits of the McAlister Range and Mt. Mueller, with leaves narrower and smaller and not rugose, and with an inflorescence, which is axillary, and a transverse downy curved 
line inside at the base of the upper lip of the calyx,-—characters absent in my species.

Following the classification of Bentham, I have placed this species in the Series Racemosæ from its terminal spikes; and in botanical sequence after $P$. denticulata, having greatest affinity with that species, whilst resembling and possessing also some of the characters of $P$. rugosa and P. marifolia.

\section{EXPLANATION OF PLATES.}

Plate XXII.

\section{Prostanthera discolor.}

Fig. 1.-Twig showing inflorescence.

Fig. 2. -
Fig. 3. Individual flowers (enlarged).

Fig. 4-

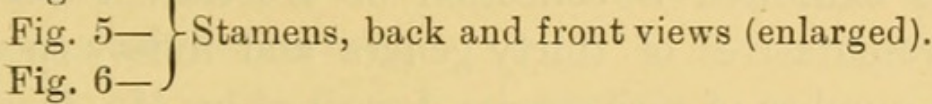

Fig. 7-Pistil and ovary.

Plate XXıII.

Prostanthera stricta.

Fig. 1-Twig with inflorescence.

Fig. 2-Individual flower (enlarged).

Fig. 3-Calyx showing bracts (enlarged).

$\left.\begin{array}{l}\text { Fig. } 4- \\ \text { Fig. } 5-\end{array}\right\}$ Stamens with appendages (enlarged).

Fig. 6-Calyx with seeds (enlarged).

Fig. 7-Seed (enlarged).

\section{EUCALYPTS AND LORANTHS IN THE RELATIONS} OF HOST AND PARASITE: AND AS FOOD PLANTS.

\section{By J. J. Fletcher.}

The object of this paper was to introduce a discussion of the question whether, as has been stated, certain Loranths may be said to mimick Eucalypts. 


\section{$2 \mathrm{BHL}$ Biodiversity Heritage Library}

Baker, Richard T. 1896. "Two new species of Prostanthera from New South Wales." Proceedings of the Linnean Society of New South Wales 21, 378-381. https://doi.org/10.5962/bhl.part.8478.

View This Item Online: https://www.biodiversitylibrary.org/item/30483

DOI: https://doi.org/10.5962/bhl.part.8478

Permalink: https://www.biodiversitylibrary.org/partpdf/8478

\section{Holding Institution}

MBLWHOI Library

\section{Sponsored by}

MBLWHOI Library

\section{Copyright \& Reuse}

Copyright Status: NOT_IN_COPYRIGHT

This document was created from content at the Biodiversity Heritage Library, the world's largest open access digital library for biodiversity literature and archives. Visit BHL at https://www.biodiversitylibrary.org. 